УДК 658.84:004.738

DOI https://doi.org/10.32837/pyuv.v0i4(39).909

\section{О. А. Теличко \\ orcid.org/0000-0003-2536-7442 \\ кандидат юридичних наук, \\ в. о. завідувача кафедри правового регулювання еконоліки Державного університету економіки і технологій}

\author{
В. А.Рекун \\ orcid.org/0000-0002-2636-9426 \\ кандидат юридичних наук, \\ доиент кафедри правового регулювання еконоліки \\ Державного університету економіки і технологій
}

\title{
ОНЛАЙН-ВРЕГУЛЮВАННЯ СПОРІВ У СФЕРІ ЕЛЕКТРОННОЇ КОМЕРЦІЇ ЯК АЛЬТЕРНАТИВНИЙ СПОСІБ ДОСУДОВОГО ВРЕГУЛЮВАННЯ КОНФЛІКТІВ
}

Впродовж останнього десятиріччя в Україні та в усьому світі активно розвиваються і набирають дедалі більшої популярності альтернативні способи вирішення (врегулювання) спорів (далі «ABC»). У літературі під такими способами мають на увазі сукупність процедур, які сприяють позасудовому вирішенню спорів. У різних країнах до таких процедур належать різні позасудові форми вирішення спорів. Найбільш популярні - медіація, арбітраж (третейський розгляд), переговори та судове примирення.

Актуальність дослідження зумовлена тим, що наразі українська правова система перебуває на етапі модернізації, відбувається активне реформування законодавства, ухвалення нових законів і внесення безлічі поправок в уже наявні. Ці зміни продиктовані насамперед тенденціями глобалізації та включенням України в загальноєвропейську правову сім'ю з притаманними їй правовими стандартами захисту прав людини й етики економічного обороту.

Постановка проблеми. На відміну від країн Європи і Заходу, в Україні найбільш поширеною формою захисту порушених прав є судова, незважаючи на те, що Конституція надає можливість громадянам самостійно захищати свої права i свободи всіма не забороненими законом способами. Водночас судова форма захисту має суттєві недоліки: вона зумовлює чималі процесуальні витрати, тяганину і завдає шкоду діловим відносинам сторін, надає небажаного розголосу. В більш глобальному масштабі виникає серйозне перевантаження судових органів, яке позначається на ефективності та якості їхньої роботи. Правове середовище сучасної України є простором, в якому паралельно функціонують дві системи вирішення спорів. Одна, традиційна, використовує усталені інститути судової влади. Інша система включає новоутворені альтернативні структури, переважно запозичені з зарубіжної практики. Але наразі система альтернативних способів вирішення спорів є інтегрованою в українське правове середовище, процес інтеграції якого дотепер не завершено.

Аналіз останніх досліджень і публікацій. Враховуючи високий рівень актуальності наукових праць у сфері вивчення особливостей існування електронної комерції, її дослідження перебуває в центрі уваги багатьох вітчизняних і зарубіжних учених. Вивченням електронної комерції та її особливостей на вітчизняному ринку займалися такі науковці: Л.В. Кислюк, Д.Г. Легеза, С.В. Маловичко, О.І. Шалева, Н.Т. Гринів, Л.І. Третьякова, С.Й. Чучмарьова, серед зарубіжних авторів можна виокремити Ф. Котлера, Р. Уілсона, А. Хартмана, У. Хенсона, В. Холмогорова, Є.П. Голубкова, I.В. Успенського, Т. Кеглера, М. Ліндстрома тощо.

Постановка завдання полягає у комплексному дослідженні онлайн-врегулювання спорів у сфері електронної комерції як альтернативного засобу досудового врегулювання конфліктів та внесенні пропозицій щодо способів їх імплементації у вітчизняну практику.

Виклад основного матеріалу дослідження. Розвиток інформаційних технологій, цифровізація економіки, інтенсифікація торговельних відносин у транскордонному просторі, збільшення фінансових і торговельних транзакцій, здійснюваних за допомогою комп'ютерних мереж, а також необхідність пошуку адекватних й ефективних способів врегулювання суперечок в епоху поєднання традиційної і цифрової економіки створюють передумови для розвитку електронної системи альтернативних механізмів вирішення спорів.

Онлайн-врегулювання спорів (далі - ОВС) це сукупність методів врегулювання спорів із застосуванням інтернет-технологій $[1$, с. 2], яка розглядається західними юристами як онлайн-еквівалент методів альтернативного врегулювання спорів, що включає у себе переговори, медіацію, Третейський суд. Впровадження інноваційних 
технологій дозволяє значно розширити можливості цих традиційних процедур. Така процедура застосовується для вирішення низки проблем: від міжособистісних суперечок до національних конфліктів. Наразі ОВС набуває популярності у вирішенні конфліктів у сфері електронної комерції [2, с. 1]. Найбільш поширене ОВС у США, Канаді, Європі та Австралії.

ОВС - процедура, що з'явилася внаслідок взаємодії альтернативного врегулювання спорів та інформаційно-комунікаційних технологій. Як метод ця процедура виникла в процесі взаємодії людей та організацій, для яких традиційні методи виявилися неефективними. Американські дослідники E. Katsh i J. Rifkin назвали OBC четвертою стороною врегулювання спорів [3, с. 18]. Багато в чому саме четверта сторона підвищує ефективність процесу врегулювання конфлікту та сприяе його припиненню.

Наразі онлайн-методи врегулювання конфліктів в англомовній практиці позначаються різними термінами, що нерідко призводить до плутанини, особливо серед тих, хто не знайомий із цим напрямом альтернативного врегулювання спорів. Зокрема, використовуються такі формулювання:

1. Інтернет-вирішення спорів (Internet Dispute Resolution - iDR).

2. Електронне вирішення спорів (Electronic Dispute Resolution - eDR).

3. Електронне альтернативне врегулювання спорів (Electronic ADR - eADR).

4. Онлайн-альтернативне врегулювання спорів (Online ADR - oADR).

Найбільш використовуваним англомовним терміном в останні роки є «онлайн-врегулювання спорів» (Online disputere solution - ODR) [4, c. 68].

Слід зазначити, що на міжнародному рівні питанням онлайн-врегулювання спорів приділяється підвищена увага. Зокрема, зазначеному питанню присвячений Регламент (ЄС) № 524/2013 Європейського Парламенту та Ради від 21 травня 2013 р. про врегулювання суперечок онлайн [5], відповідно до якого в ЄС створена інтернет-платформа з вирішення спорів онлайн.

Технології онлайн-врегулювання суперечок можуть бути застосовані як до судових процесів, так і до альтернативного врегулювання спорів.

Вирішення спорів в інтернеті стало популярним в разі врегулювання конфліктів у галузі електронної комерції серед підприємств і споживачів. На нашу думку, переваги онлайн-вирішення спорів включають [6, с. 1]:

1) вартість. Вирішення спорів в інтернеті часто дешевше, ніж традиційний правовий процес;

2) ефективність. Онлайн-вирішення спорів часто може швидко вирішити суперечку, на відміну від судового розгляду;
3) участь і контроль. Сторони, що використовують онлайн-вирішення спорів, повинні співпрацювати для врегулювання суперечки і часто мають більший контроль над результатом справи;

4) географічну гнучкість. Вирішення онлайнспорів може відбуватися в різних місцях або країнах, це дозволяє уникнути витрат і незручностей у поїздках.

Кожна форма ОВС може використовувати різні технологічні системи, індивідуалізуючи перебіг цього процесу. Онлайн-посередництво може набувати різних форм: від повністю автоматизованої інтернет-платформи з використанням порталу на основі електронного чату або відеоконференції (The Mediation Room.com) до виняткового використання асинхронної форми зв'язку, тобто за допомогою таких методів, як електронна пошта (Risolvi Online.com) [7].

Перший варіант утворює систему, що включає відеозустрічі або онлайн-бесіди (чати), під час яких аналізуються можливості вирішення спорів за допомогою посередника - більш прямої форми OBC. Інший варіант застосовується, наприклад, за посередництва в межах грошових зобов'язань. Використовуючи систему наданих пропозицій, сторони погоджуються із сумою, прийнятною для всіх, без необхідності прямої зустрічі. Електронний арбітраж, який належить до світового розгляду, що проведено через інтернет, може набувати або синхронну (наприклад, Smartsettle), або асинхронну форму (SettleToday).

Популярний спосіб урегулювання спорів електронний арбітраж. Це процедура вирішення розбіжностей нейтральною особою, уповноваженою на винесення обов'язкового для сторін рішення. Недоліками такої процедури є невизнання електронної форми документа належною, проблема ідентифікації, проблема забезпечення конфіденційності у кіберпросторі.

Аналогічно дедалі популярнішими стають електронні переговори. Прямі переговори здійснюються за допомогою електронної пошти або вебсайтів провайдерів OBC-послуг. Автоматизовані переговори - це вирішення спорів на основі математичного алгоритму. На початковому етапі сторони визначають умови і пропозиції, за яких система автоматично повинна буде врегулювати розбіжності. В разі досягнення умов суперечка автоматично врегулюється. Недоліком автоматизованих переговорів є те, що вони підходять лише для врегулювання суперечок, єдиною розбіжністю яких є розмір грошової суми або кількісна характеристика предметів.

Віртуальний суд присяжних - звернення через інтернет-мережу за порадою до невизначеного широкого кола осіб. Сторона розміщує опис обставин суперечки, вимоги сторін, докази. Для більш глибокого аналізу присяжні під час реєстрації по- 
відомляють відомості про себе (стать, вік, освіта). Таким чином, сторонам надається можливість реально оцінити свої позиції у справі.

Онлайн-посередництво пропонує широкий спектр методів реалізації, підтверджених галузями, які найшвидше зростають: споживчим i сімейним законодавством. Однак багато юридичних питань, такі як класифікація порушень або юридична відповідальність, не можуть бути вирішені за допомогою електронного посередництва. Відсутність прямого контакту в процесі посередництва не сприяє створенню довіри, що є основою для направлення позову, який має бути врегульовано будь-якими позасудовими процесами. Електронний зв'язок, незважаючи на його очевидну доступність, може також створити низку розумових бар'єрів, які перешкоджають ефективному посередництву.

Емпіричні дослідження методів ОВС доводять, що вони найбільш ефективні для спорів із низьким рівнем складності. Правові відносини між сторонами, що конфліктують, з конкретним характером і типом претензії та на основі чітких положень можуть бути піддані методам ОВС. Необхідно створити правову основу з використанням таких електронних інструментів, як платформи та інтернет-портали, що дозволять автоматично вирішувати спори без необхідності юридичної класифікації та тривалих слухань.

Незважаючи на очікуване збільшення використання ОВС в ЄС для реалізації положень директиви «ABC» і вирішення суперечок між споживачами, ці методи не стануть звичайним явищем, оскільки вони належать лише до конкретних видів суперечок. Схоже, що посередництво й арбітраж будуть підтримуватись електронними повідомленнями частіше, але це не означає, що всі їх процеси будуть передані в інтернет, а посередники та арбітри будуть замінені комп'ютерними програмами [8].

Наразі Україна перебуває на етапі вироблення фундаментальних основ концепції онлайн-врегулювання спорів у сфері електронної комерції для того, щоб така форма вирішення спорів стала повсякденною як у вітчизняній практиці, так і у взаєминах України з її іноземними контрагентами.

Висновки. Для формування й ефективного функціонування інституту онлайн-врегулювання спорів у сфері електронної комерції в Україні необхідно, на нашу думку, розробити порядок його поетапного впровадження. До основних напрямів створення електронної системи альтернативних механізмів вирішення спорів слід віднести:

1) концептуальне визначення соціальних та економічних завдань, вирішення яких має сприяти впровадженню електронних систем альтернативних механізмів вирішення спорів;
2) створення умов для підвищення рівня довіри учасників економічного обороту до онлайн-механізмів врегулювання спорів;

3) визначення спектру застосування інструментарію онлайн-врегулювання спорів;

4) надання сторонам суперечки вільного вибору способу врегулювання спору, який передбачає диференціацію меж використання системи онлайн-врегулювання спорів i виключення абсолютизації процедур розгляду спорів у третейських судах, включаючи комерційний арбітраж.

У межах реалізації цих напрямів необхідне збереження таких переваг альтернативного вирішення спорів, як конфіденційність, захист даних учасників, належна кваліфікація, незалежність і неупередженість сторонніх осіб, які сприяють сторонам у врегулюванні суперечок, тощо.

\section{Jimepamypa}

1. Ahalt A. What You Should Know about Online Dispute Resolution. URL: http://montyahalt.com/ know-about-online-dispute-resolution/ (дата звернення: 07.10.2021).

2. Bygrave L. Online Dispute Resolution - What it Means for Consumers. URL: http://folk.uio.no/lee/ oldpage/articles/Bygrave_ODR.pdf (дата звернення: 07.10.2021)

3. Katsh E., Rifkin J. Online Dispute Resolution: Resolving Conflicts in Cyberspace. San Francisco : JosseyBass, 2001. 226 p.

4. Миронова С.Н. Использование возможностей сети Интернет при разрешении гражданско-правовых споров. Москва : ВолтерсКлувер, 2010. 256 с.

5. Regulation (EU) № 524/2013 of the European Parliament and of the Council of 21 May 2013 on Online Dispute Resolution for Consumer Disputes and Amending Regulation (EC) № 2006/2004 and Directive 2009/22/EC (Regulation on Consumer ODR). URL: https://eur-lex.europa.eu/legal-content/EN/TXT/?uri= celex \% 3A32013R0524 (дата звернення: 08.10.2021).

6. What is Online Dispute Resolution? A Guide for Consumer. URL: https://www.americanbar.org/ content/dam/aba/migrated/2011_build/dispute_ resolution/consumerodr.authchec kdam.pdf (дата звернення: 11.10.2021).

7. Mania K. Online dispute resolution: The future of justice. International Comparative Jurisprudence. Vol. 1. Issue 1. November 2015. P. 76-86. URL: https://www.sciencedirect.com/science/article/pii/ S2351667415000074 (дата звернення: 11.10.2021).

8. Equal Access to Information and Justice Online Dispute Resolution. ICC official website. URL: https://iccwbo.org/event/equal-access-information-justice-online-dispute-resolution/ (дата звернення: 12.10.2021).

\section{Анотація}

Теличко О. А., Рекун В. А. Онлайн-врегулювання спорів у сфері електронної комерції як альтернативний спосіб досудового врегулювання конфліктів. Стаття.

У статті розглянуто альтернативні способи вирішення (врегулювання) спорів у сфері електронної 
комерції, які активно розвиваються і набирають дедалі більшої популярності в усьому світі загалом і в Україні зокрема. Проте наразі система альтернативних способів вирішення спорів у сфері електронної комерції хоч і є інтегрованою в українське правове середовище, але процес її інтеграції дотепер не завершено.

Проаналізовано процес впровадження інформаційно-комунікаційних технологій у сучасну систему альтернативних механізмів вирішення спорів, який у зарубіжній правозастосовній практиці заведено позначати терміном «онлайн-врегулювання суперечок». Онлайн-врегулювання суперечок - це сучасний інструмент для врегулювання спорів, що виникають як між постачальниками та продавцями (або операторами електронних торговельних майданчиків), так і між цими групами осіб та споживачами в цифровому середовищі, що становить нагальну проблему у веденні транскордонного бізнесу (особливо малого і середнього підприємництва). Незважаючи на актуальність визначеного питання, більшість країн, зокрема й Україна, перебувають на початкових етапах дискусії, а також розвитку національного і міжнародного регулювання.

Висвітлено сфери застосування цієї системи й основні методи, використовувані для ОВС. Особлива увага приділяється аналітичному огляду міжнародних ініціатив у межах повсюдного впровадження ОВС як перспективної і сучасної системи альтернативного вирішення спорів («ABC»). У статті надано якісну оцінку поточного статусу розвитку OBC у зарубіжних країнах, наведені практики, які вже застосовуються закордонними підприємствами в межах цієї системи. Зроблено висновки і практичні рекомендації щодо подальшого розвитку ОВС в Україні.

Ключові слова: електронна комерція, альтернативне врегулювання спорів, онлайн-врегулювання суперечок, онлайн-платформи врегулювання суперечок, електронний арбітраж, електронні переговори, віртуальний суд присяжних, онлайн-посередництво.

\section{Summary}

Telichko O. A., Rekun V.A. Online dispute resolution in the field of e-commerce as an alternative method of pre-trial dispute resolution. - Article.

The article considers alternative ways of resolving (settling) disputes in the field of e-commerce, which are actively developing and gaining more and more popularity around the world and in Ukraine. However, to date, the system of alternative dispute resolution in the field of e-commerce, although integrated into the Ukrainian legal environment, the integration process has not yet been completed.

The process of introduction of information and communication technologies in the modern system of alternative dispute resolution mechanisms is analyzed, which in foreign law enforcement practice is usually referred to as the online settlement of disputes. ODR is a modern tool for solving one of the most acute, but not unresolved problems in conducting cross-border business (especially small and medium enterprises) to resolve disputes that arise between suppliers and sellers (or operators of electronic trading platforms), and between data groups of individuals and consumers in the digital environment. Despite the urgency of this issue, most countries, including Ukraine, are in the early stages of discussion, as well as the development of national and international regulation.

The spheres of application of this system, and also the basic methods used for ODR are covered. Particular attention is paid to the analytical review of international initiatives in the framework of the widespread implementation of the ODR as a promising and modern system of alternative dispute resolution (ADR). The article gives a qualitative assessment of the current status of the development of police in foreign countries, presents the practices that are already used by foreign companies within this system. Conclusions and practical recommendations for further development of police in Ukraine have been made.

Key words: e-commerce, alternative dispute resolution, online dispute resolution, online dispute resolution platforms, electronic arbitration, electronic negotiations, virtual jury trial, online mediation. 